\title{
Téoros
}

Revue de recherche en tourisme

\section{Some Questions of Ethics related to Global Distribution Systems}

\section{Chris Lyle}

Volume 14, numéro 3, automne 1995

Tourisme et technologies de l'information

URI : https://id.erudit.org/iderudit/1075086ar

DOI : https://doi.org/10.7202/1075086ar

Aller au sommaire du numéro

Éditeur(s)

Université du Québec à Montréal

ISSN

0712-8657 (imprimé)

1923-2705 (numérique)

Découvrir la revue

Citer cet article

Lyle, C. (1995). Some Questions of Ethics related to Global Distribution Systems.

Téoros, 14(3), 35-39. https://doi.org/10.7202/1075086ar d'utilisation que vous pouvez consulter en ligne.

https://apropos.erudit.org/fr/usagers/politique-dutilisation/ 


\section{SOME QUESTIONS \\ OF

Chris Lyle
is the Chief of the Economics
and Statistics Branch with the
International Civil Aviation
Organization in Montreal.
The views expressed here
are his own.
(e-mail: atb@iCA0.arg)
(http://www.com.org/ /CA0
tems for distribution through travel agents recognlzed and explolted.

Coincldent with developments in automation alr transport entered an era of progressively reduced goverument regulation and Increased competition, leadlng both to a greatly Increased rellance by alrlines on travel agents and to a greatly Increased rellance by travel agents on computer reservation systems as their primary informatlon source. In the United States today well over 80 per cent of alrllne tickets are sold through travel agents and 97 per cent of travel agents are automated. In other reglons these proportlons are lower, but they are growing fast.

Liberallzation of alr transport was also assoclated with consolldation and globalization, both of airlines and of their reservation systems, and today there is an ollgopoly of four systems with global reach (In some cases acliteved through partnershlp with a reglonal system):

- Amadens/Systemone

- Gallleo

- SABRE

- Worldspan

Ownership of each of these systems is domlnated by a few atrlnes (in the case of SABRE by a single alrline) from the United States and/or Europe. A further system, GETS (owned by the Société internationale de télécommuntcatıons aéronautiques, SITA, a non-profit multi-alrline owned company). Is In a slightly different category in that it is designed primar'ly for smaller alrlines to distribute their product In thelr own countrles and its activities are essentlally limited to Africa, eastern Europe and Latin America.

An Important factor is that development of GDS was airline driven and all GDS are effectlvely alrline controlled. But the alrines concerned are well aware of the additional revenues that can be obtained through thelr GDS by the Incluslon of other elements of the travel and tourlsm product such as car hire, hotels, theatres, etc, and these are now commonly accessible. However, alrine reservatlons remaln the domlnant source of travel agency revenue and, for varlous rea- sons, automation is far more dominant In alrline reservations than In other travel and tourism services.

GDS have provided substantial benefits for alr carriers, travel agents and passengers allke. They enable Information to be distributed and reservatlons to be processed in an extremely efficlent manner, and In many markets they have become an essentlal business tool. However, there has also been some abuse of GDS which has led. actually or potentlalIy.

- as far as alrilines are concerned, to a detrimental Impact on falr and equal opportunity to compete

- as far as travel agents are concerned. to mlsrepresentathon of the Information avallable to them

- as far as GDS vendors are concerned, to abuse of market power offered by the monopoly characteristics they mallitain lı many markets.

The ramiflcations are farreaching, and have Included retaltatory action by airines and travel agents as well as regulatory action by governments. In a few cases travel agents have even managed to set up thetr own reservation systems which have the merit of including a wide range of national travel Information ("destination databases", etc) beyond that covered by a GDS. but meluding access to a GDS as one element In thelr system. However, each of these travel agency systems in effect distributes just a single GDS, which may or may not be the best one for the market according to the transaction concerned. And these "dest.Inatlon databases" are not generally accessible from other countries (a "recelvIng" agency understandably not wishing to provide the opportunity for Its commission to go elsewhere), thereby restrictIng the avallability of valuable information for consumers.

As for govermment regulation. In most economlc sectors the concerns ralsed would be covered by natlonal competition law and international trading arrangements. GDS are speclal to the extent that their dominant function relates to the sale of air transportation, the commerclal operation of which Is based on speclal regulatory regimes, notably so In the case of International carrlage wlitch is largely governed by a vast number of bllateral alr services agreements between States. And one of the key Issues relates to the selection and ordering of fllghts on the screen, which can be used to Impalr the value for alrlines of their rights in these agreements to market access and to "falr and equal opportunilty" to compete. For the purposes of this brlef article screen display for airlines will serve as an Illustratlon of one of the fundanental ethical questlons related to GDS: are they fair to alrlines? to travel agents? and. last but not least. to passengers? 


\section{Evolution of screen display}

In the early days of civil avlation, Information on alrine schedules and fares was distributed by indivldual alrline companles in the form of printed timetables or newspaper advertisements. Since the flights and fares were few and simple and the cholce of alrlines and noutings was very IIm Ited, passengers could thereby readily be made aware of all the products offered. As an increasing plethora of fares and services became avallable and airline fourneys Involving two or more alrlines became more commonplace, however, a need was seen for consolldation of the various alrline timetables for easy reference.

For many years thls need was met by publlshers of mult/-carrler schedule or tarlff guldes such as the ABC World Alrways Gulde, the Offlclal Alrline Gulde (OAG) the Alr Tariff and the Alr Passenger Tariff, which Included the schedules and/or fares of the vast majority of alrlines worldwide. With passengers seeking guldance in selecting the varlous optlons avallable, and with alrlines concomltantly seeklng to sell their services in a wide varlety of locatlons, the comblnation of the travel agent and the multi-carrler guide became an increasingly common tool for marketing alrine tickets.

Both the $\mathrm{ABC}$ and the OAG, in presenting integrated schedule information, Ilsted for each citypalr: first, direct filghts (whether nonstop or stopping) in order of departure time: and second, connecting flights in order of departure time; together with indlcators of the days of the week on which the flights operated. All of the servlce optlons for a cltypalr, even for those cltypalrs with the most extensively listed range of optlons, could readlly be encompassed on a single page of a printed alrine gulde. Very few substantive concerns liave ever been ralsed by passengers, alrlines or govermments about the approach to llstings used by these guldes.

A baslc problem appears to have been created, or at least exacerbated, by the electronlc age. Travel agents now increasingly rely on information provided through GDS which are capable of glving easy access to much greater ranges of service options than the printed guides. At the same time the concept of an Integrated schedule display for airlines has been malntalned (In some cases through government action). In marked contrast to the reservation systems for hotels or rental cars, where the travel agent Is simply presented with a switching facllity between the reservation systems of indlividual hotel chains or car rental companles without an lutegrated display.

As regards the integrated airline displays, recognizing that relatively few of the servlce optlons avallable will generally be of Interest, to a particular passenger, GDS vendors liave found a need to move away from the listing procedures used by the printed guides in order to provide the travel agent and Its cllent with selective listings of service optlons, ranked in a manner which the vendor presumably feels wlll most adequately reflect customer preferences.

A problem arises, however, In that there is only room on the computer terminal for presentation of a very few options at. one time (in some cases no more than four flights on the screen at a time). Travel agency staff, who frequently operate with very tight time and resource limited budgets, and despite their speclalist knowledge of particular markets, naturally have a tendency to select from the most readly accesslble flight, one from amongst the first optlons presented (the probability of selection of the first flight on a screen being hlgher than the second flight, the probability of selection of a flight, from the first screen being higher than a flight from the second screen, and so on). The ranking of flights on the screen by the GDS vendor can therefore be of critical commerclal importance.

The days of the most blatant abuses of ranking. whereby an alrine owning a reservation system might list its own flight frst and that of a competitor lower down or even not at all, are past, onsted not only by government regulations (notably In Australla, Canada, Europe and the United States) but by the needs of travel agents to have a comprehensive and nondiscrim inatory data base to best serve their cllents.

Nevertheless, there remain a wide varlety of screen display criterta lin existence and, Interestingly enough, none of them apparently follows the ordering used in the printed guldes. Some of these varlants have created considerable concerns. whth alrlines reporting examples of what they percelve as slgniflcant blas agalnst thelr own operatlons, and passengers reporting mlsrepresentation to them of services. Consequently, a number of governments are Insisting that the ordering of flights on a screen must be prescrlbed by reg. ulation. The question then is what order, if any. should be prescribed?

\section{Illustrating the problem}

Let us flrst show the impact of varlous possibllitles on a very stralghtforward, single sector operation. MontrealToronto. If flights are slmply llsted In chronological order during the day, as was the case in the $A B C$ and $O A G$. In the summer of 1995 you might lave got the IIsting appearing In Flgure 1.

This listing has a number of interesting features. For example, right at the top. Air Canada (AC) flight 117, which is scheduled to leave at 0645 is Ilsted ahead of Canadlan Arlines (CP) fllght 961, which is scheduled to leave at exactIy the same time but with a one mlunte longer flight durathon. In the spring of 1995 , Alr Canada's flight had been scheduled as belng three minutes slower than In the summer, arrlving at 0755 , and on the same llst lng appeared after the Canadlan flight!

The third flight listed, $A C 1371$, Is assoclated with an asterlsk to Indicate that it is "codeshared"; In practice it is an AIr Ontarlo Dash 8 service to Toronto Island AIrport which, despite being longer and arriving (In metropolitan Toronto) later, sneaks In ahead of the new Asloria (S3) 737 service because of its earller departure thme.

But perliaps the passenger does not wish to get up at crack of dawn for an 0645 departure and would prefer to leave around, say, 0900. With the chronologlcal IIsting in Figure 1 a travel agent would have to scroll down to the middle of the third screen to flnd an 0900 departare. In practice, all GDS 
make the search easler by catering to a departure (or arrival) time request, but the question is how to do this. If the GDS vendor were simply to list all flights with a departure tume of 0900 or later, the flrst screen listing might appear as in box "A" In Flgure 1, with Air Canada flight 405 at the top. With this approach Astorla flight 711, which in practice is nearly as attractive from a scheduling perspectlve as AIr Canada filght 405, and more so than all subsequent flights listed, would not appear at all!

GDS vendors improve on thls approach by opening a "win= dow" starting a prescrlbed perlod (often 2 hours) before the requested departure tume. This can, however, only be a parthal remedy. For example, in the high density market Illustratlon of Montreal Toronto, opening the llsting 2 hours before the requested departure time of 0900 would produce Screen 2 In Flgure 1 as the first screen and the flights closest to 0900 would still not appear on that screen. Conversely, in a lower density market a flight departing Just over two hours before the requested departure tume would be IIsted after one leaving several hours after the requested departure time or perhaps not at all.

Another approach is to list the flights In order of the "displacement" between the requested departure time and the actual departure time, the result for the Montreal Toronto Illustration being shown in Figure 2. In thls Iisting. Astorla flight 711 , being only 15 minutes away from the requested departure time of 0900 , appears Immedlately after Alr Canada flight 405.

In practlce this approach, where applled, is usually taken one step further to accommodate not only displacement, but also the elapsed time of the journey, which is particularly Important where stopplng and connecting filghts are concerned because of the delay for the stops and between connectlons. Under this approach, as can be seen from Flgure 2. a requested departure time of 0930 would place CP863 (displacement 0020 , elapsed 0110 , total 0130) first, ahead of the slower (Alr Ontario Dash 8) AC1377 (displacement 0005 , elapsed 0128 , total 0133 ).

The effect of this approach is illustrated in Figure 3, relating to Montreal Miaml. The fllghts are listed in the chronologlcal order that they appear in a printed multi-carrler gulde, but four out of flve of them are early morning departures and would clearly not sult someone wishing to travel in the afternoon. The "dlsplacement plus elapsed" approach for a requested departure time of 1600 would, however. llst the one afternoon flight flrst and the 0850 departure second (and would list the two 0655 departures before the 0705 one because of the time taken up by the latter for a stop en route).

The Montreal-Mlainl listing in Flgure 3 also provides a different example of a "code-shared" servlce, filght AA479 being operated by American AIrlines but also belng marketed as CP6248 by Canadlan. Discussion of the pro- and aitl-competitive aspects of code-sharing is beyond the scope of this article, but one effect of It (often called "screen padding") can be to drive a competitor's flight down the ranking (in this case the "double listing" of the same filght pushes UC361 from Screen 1 to Screen 2).
The examples in Flgures 1 through 3 are extremely simple, Inwolving solely non-stop or direct services. They nevertheless Illustrate an Issue which can become cruclal in markets with a varlety of service options, particularly where there are few If any direct filghts and connections are the norm. Just as an example of what can happen, a request from one GDS for Montreal Bangkok optlons produced a printout of more than 50 screens' worth of optlons and the flights with the shortest elapsed time were not found until the 30th screen!

The concept of using displacement plus elapsed tIme as the ranking criterion would have been of particular value in this Instance. However, this concept has not been taken up by governments (one possible reason being that, at least at flrst sight, It Is not as transparent as a chronological departure or arrival time listing) and those GDS that use it have added some somewhat subjectlve quirks to the basic formula. For example, In the case of connecting fllghts, they will use the true displacement plus elapsed time (Including the time between connections) for "on-line" (same alrline) servlce but may add an artiflclal "penalty" of 30,60 , 90 or even 120 minutes in the case of an interline servlce, depending on their perception of the consumer preference for on-line service in the market concerned. What is more, where there is a connection between two alrilines which share a common code over the whole journey concerned (the most common application of code-sliaring) the connection is usually treated as "on-IIne", thereby gaining ranking and competitive advantage: a measure of the extent of this advantage may be ascertalned from the phenomenal growth of the multitude of code-sharing arrangements now in place right around the world.

\section{Seeking a solution}

Some governments, notably in Europe, have taken a somewhat different approach, also differing from the $\mathrm{ABC} / \mathrm{OAG}$ formula, by prescribing that service optlons for the day(s) requested must be listed In the following order: ftrstly, all non-stop flights IIsted in order of departure tume: secondly. all direct flights, not. Involving change of alrcraft. Ilsted in order of elapsed fourney the; and thlrdly, connectung services, llsted in order of elapsed journey time. While this formula has the advantage of belng simple, precise and transparent, Its very simplicity means that It cannot solve all the problems. For example, the assumptlon that a non-stop fight is always preferable to a stopping one has considerable valldity In a dense, short-haul market, but has less credibillty In other markets (as a very simple example, for a passenger wishing to depart in the afternoon from Montreal for MlamI, the 1630 one-stop departure In Flgure 3 may be preferable to the 0850 non-stop). And whlle elapsed time is clearly a key parameter, In the absence of a departure/arrival related parameter (for example, dlsplacement), a listing can remain very confusing given the multitude of dlrect and connecting flight options that are on offer in many markets. Also, in the absence of a requested departure or arrival time. GDS vendors generally apply a "default" time which may vary from market to market and could be used in a discriminatory manner to promote the flights of particular carrlers in the llstings.

The prescriptive approach to screen dlsplay by governments thus goes some way to precluding the worst abuses, but the 
benefits of consistency and simplicity are countered by the varying requlrements of different markets (e.g. short-haul versus long-haul, dense versus thin), the wide range of passenger preferences, and the technological and entreprenenrlal room left to get round the prescriptlon. Governments would need mlcro-manage prescription in order to cover all the angles (for example in defining the nature of the "windows" according to clrcumstance). Thls is exacerbated by the abllity of a travel agent to amend the screen presentatlon at hls or her terminal; some governments have directed that any display other than a "neutral" one provlded by the GDS vendor may only be used to meet a preference Indicated by the passenger but this is in practice almost Impossible to pollce, and a travel agent can sometimes be influenced by the commission levels paid by different airlines as well as by passenger needs.

Other governments, notably In Australla, Canada and the United States, have taken the vlew that, subject to general provisions that displays not be influenced, directly or Indlrectly, by the Identity of carrlers or alrports, the partlcular methodology used for ordering flights should be left to the marketplace (as long as It Is consistently applled).

\section{Conclusion}

In practice, as passengers become more knowledgeable about alr travel, their rellance on an Integrated ordering of flights to determine their alrline and filght selectlon Is likely to dimlnish. For example, many corporate passengers are more Interested in a screen display which offers them a means of earning "frequent flyer" mlles (often at some sacrlflce of schedule convenlence) and most tourists in one which offers them the lowest possible fares rather than the Ideal schedule (and these fares may not necessarly be published alrline fares since some travel agency consortia have negotlated "private" fares which are held separately in the GDS).

Thls knowledge is Ilkely to Increase rapldly with the spread of Information on schedules and fares directly to potentlal passengers through personal computers and the INTERNET. Tlcketing, sales and promotlon costs have risen to the polut where they currently represent, on average worldwide, over 20 per cent of the costs of operat.ing Internatlonal passenger servlces (for comparlson, alrcraft fuel costs represent some 13 per cent), and the past couple of years have seen malor developments in distribution of the alriline product as alrines focus on reducing costs in an Increasingly competItIve envlronment. Some alrines withdrew from particlpatlon in GDS In the United States and the vendors concerned were obliged to introduce a new level of "no-frills" particlpation to get them back. Also, several alrllnes have establlshed reservatlon sites on the World Wide Web, In effect golng full clrcle to the early days of Individual alrline advertisements in the press, although they have now been followed on to the INTERNET by some travel agents anxlous not to be bypassed and even by some GDS themselves. And recently no less a power than Microsoft is reported as setting up an electronlc travel mart which poses a potential threat to the existing GDS, which are naturally concerned by a competitor that is not subject to the same regulatory reglme; a software company clearly lles outside the regulatory authority of avlation officlals.
As In so many other activitles today. IIfe is becoming more complex for travel agents and passengers allke, and one consequence Is "Information overload". In the light of this complexity and the difflculty of hitting the fast-moving targets of technologlcal advance and entrepreneurlal Ingenulty, government regulators may have to rely lncreasingly on a competlIlve marketplace to counter abuses which threaten the fundamental ethlc of falmess for all players in the GDS game vendors, alrlines, travel agents and passengers.

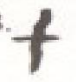

\section{Reference}

International Civil Avlation Organlzation, Code of Conduct for the Regulation and Operation of Computer Reservations Systems. ICAO Doc 9587 (pp 30-47). 1992.

Chris Lyle est le responsable de la section économique et statistique à l'Organisation de l'aviation civile internationale 


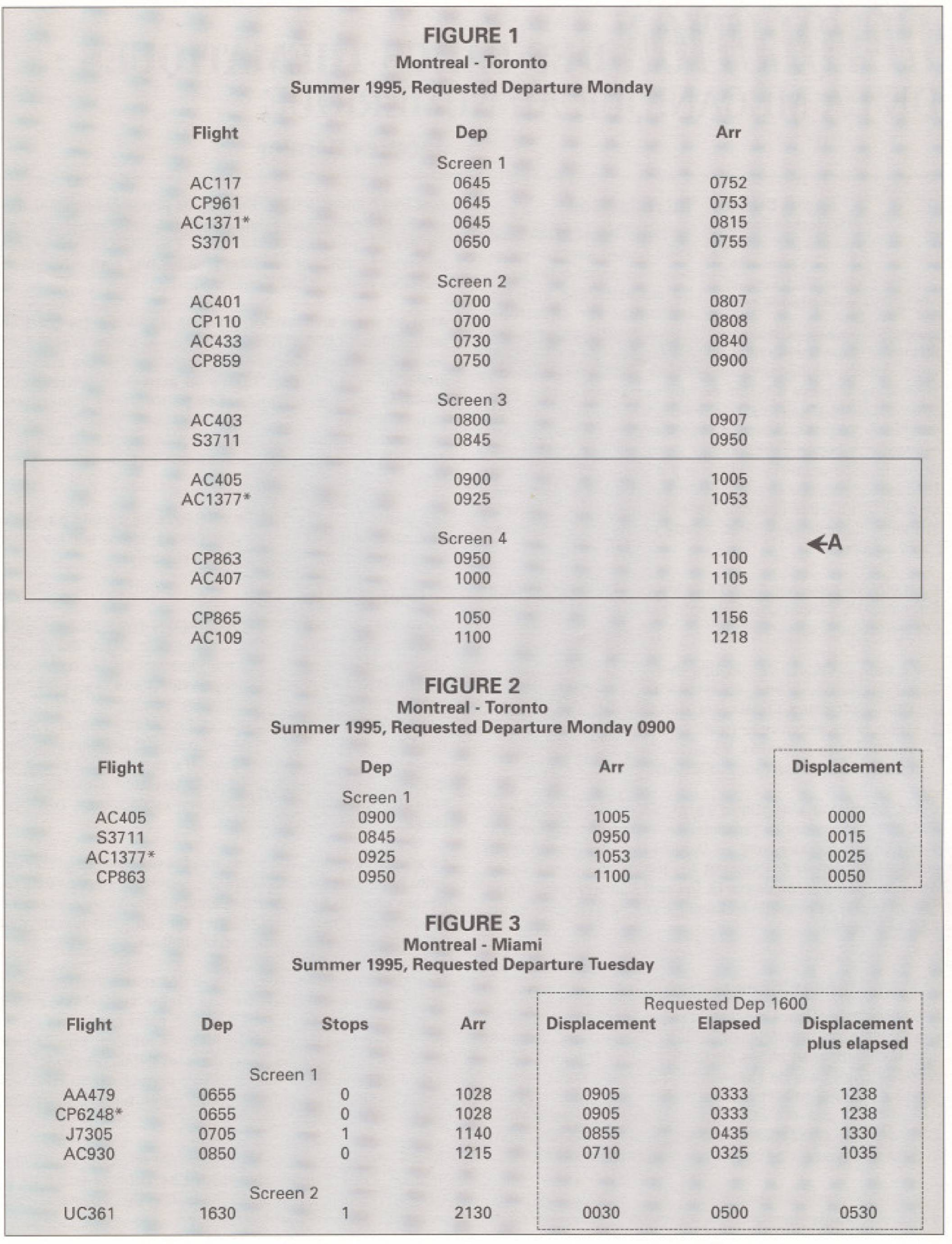

